Research Paper

\title{
Roles of B7-H3 in Cervical Cancer and Its Prognostic Value
}

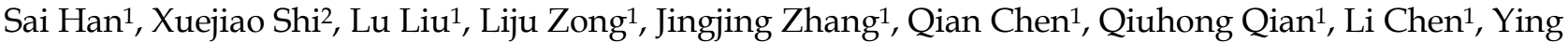 \\ Wang ${ }^{1}$, Jing Jin ${ }^{1}$, Yana $\mathrm{Ma}^{1}$, Baoxia Cui ${ }^{1}$, Xingsheng Yang${ }^{1}$, Youzhong Zhang ${ }^{1 凶}$ \\ 1. Department of Obstetrics and Gynecology, Qilu Hospital of Shandong University, Jinan, Shandong 250012, P.R. China. \\ 2. Department of Rheumatism and Immunology, General Hospital of Tianjin Medical University, Tianjin 300000, P.R. China. \\ $\triangle$ Corresponding author: Dr Youzhong Zhang, Department of Obstetrics and Gynecology, Qilu Hospital of Shandong University, 107 Wenhua Xi Road, Jinan, \\ Shandong 250012, P.R. China. E-mail: zhangyouzhong@sdu.edu.cn \\ (C) Ivyspring International Publisher. This is an open access article distributed under the terms of the Creative Commons Attribution (CC BY-NC) license \\ (https://creativecommons.org/licenses/by-nc/4.0/). See http://ivyspring.com/terms for full terms and conditions.
}

Received: 2018.01.16; Accepted: 2018.04.14; Published: 2018.06.23

\begin{abstract}
B7-H3, which has been reported to be a co-regulatory ligand of the B7 family, can suppress T cell-mediated immunity and has also been reported to be expressed in many malignancies. In this study, we found that B7- $\mathrm{H} 3$ was primarily expressed in the cytoplasm of cervical cancer cells and was associated with deep stromal invasion $(P=0.0013)$. The disease-free survival data showed that cervical cancer patients whose tumours were positive for B7-H3 expression had higher mortality rates compared with patients whose tumours lacked B7- $\mathrm{H} 3$ expression $(P=0.0317)$, representing an advantage over $\mathrm{P} 16(\mathrm{P}=0.3486)$. In contrast, the level of serum $\mathrm{B} 7-\mathrm{H} 3$ was low in cases of cervical intraepithelial neoplasia and cervical cancer. The silencing of B7-H3 in the $\mathrm{SiHa}$, $\mathrm{CaSki}$ and $\mathrm{H} 8$ cell lines inhibited cell proliferation and enhanced apoptosis, while the over-expression of B7- $\mathrm{H} 3$ in HeLa cells showed inverse changes. These changes were partially due to the regulation of cell cycle- and apoptosis-related proteins, such as E2F, P21, P16, PARP-1, Caspase-8, Bax, Bcl-2 and Bcl-xl. The results of in vivo experiments revealed that the knockdown of $\mathrm{B} 7-\mathrm{H} 3$ in tumour cells suppressed $\mathrm{SiHa}$ cell growth in nude mice. Overall, B7-H3 is involved in the development and progression of cervical intraepithelial neoplasia and cervical cancer through its effects on the cell cycle and apoptosis, which are mediated via the E7/Rb pathway. $\mathrm{B} 7-\mathrm{H} 3$ also has the potential to be a useful prognostic marker for patients with cervical cancer.
\end{abstract}

Key words: B7-H3, cervical cancer, E7/Rb pathway, proliferation, apoptosis.

\section{Introduction}

Cervical cancer is still the leading cause of death for women worldwide[1], and as the largest developing country, China has the most cervical cancer patients with nearly 30,000 deaths and 100,000 new cases reported in 2015[2]. As is well known, cervical cancer is caused by infection with human papillomavirus (HPV), especially the HPV 16 and HPV 18 subtypes. However, most infections are cleared spontaneously by the body's immune system, whereas in a subset of patients, the virus persists for years and may lead to cervical intraepithelial neoplasia $(\mathrm{CIN})$ and its subsequent transformation into cervical carcinoma. Therefore, in addition to HPV infection, other risk factors such as changes in the cervical immune microenvironment and the integration of HPV DNA into the host genome are considered important to the development of carcinoma.

B7-H3, also known as CD276, is located on chromosome 15 in humans and is a negative co-stimulatory molecule of the B7 family. It plays key roles in initial antigen priming by binding with an as yet undiscovered receptor, and its expression can be induced on dendritic cells or monocytes by inflammatory cytokines[3]. It has been reported that B7-H3 is expressed in numerous human malignancies, such as osteosarcoma, breast cancer, renal cell carcinoma, lung cancer, oesophageal cancer, prostate cancer, oral cancer, pancreatic cancer, and colorectal cancer[4-11]. All these reports suggested that the aberrant expression of B7-H3 might lead to carcinogenesis through various of mechanisms and is an indicator of poor prognosis in cancer patients. 
Despite these studies, the expression of B7-H3 in $\mathrm{CIN}$ and cervical cancer has not been investigated. In the present study, we examined the expression of B7-H3 in serum and tissue samples from patients with $\mathrm{CIN}$ and cervical cancer and analysed the relationship between B7-H3 expression and several clinicopathological variables. We also performed a series of functional experiments when B7-H3 was silenced or over-expressed in vitro and in an in vivo tumour formation model in nude mice. Together, the results suggest that $\mathrm{B} 7-\mathrm{H} 3$ may serve as a prognostic marker and a therapeutic target for patients with CIN or cervical cancer.

\section{Methods and materials}

\section{Serum and tissue samples}

Both serum and tissue samples were collected from 49 matched normal controls (benign tumours of the uterus or tissues adjacent to CIN/cervical cancer), including 15 serum samples and 34 paraffinembedded tissue samples; 45 CIN patients including 20 serum samples and 25 paraffin-embedded tissue samples; 80 cervical cancer patients including 20 serum samples and 60 paraffin-embedded tissue samples who were admitted to the Department of Obstetrics and Gynecology, Qilu Hospital of Shandong University from 2009 to 2017. All the patients were staged according to the 2009 FIGO staging guidelines[12]. Then, the clinical data including age, HPV infection, thinprep cytologic test (TCT) results, colposcopy results, and pathological diagnosis were collected from the medical record management system of Qilu Hospital. The Ethics Committee of Qilu Hospital approved this study.

\section{Immunofluorescence staining}

Anti-P16 (1:200, Abcam) and anti-B7-H3 (1:200, Abcam) primary antibodies were used to detect the expression of P16 and B7-H3, respectively, in cervical cancer cells. The experimental methods have been described previously[13].

\section{Immunohistochemical staining}

Immunohistochemical staining for P16 and B7-H3 was performed as previously described[13]. The evaluation of the immunohistochemical staining was also as previously reported. One change to mention is that the concentrations of the primary antibodies against P16 and B7-H3 were 1:250 and 1:1000, respectively.

\section{ELISA assay}

The ELISA kit used to test the serum samples for B7-H3 was obtained from Abcam (ab 221831). The expression of $\mathrm{B} 7-\mathrm{H} 3$ in the serum samples was detected according to the manufacturer's instructions.

\section{Cell lines and maintenance}

The following cell lines were used in this study: $\mathrm{SiHa}$, human cervical squamous carcinoma, HPV 16-positive; HeLa, human cervical adenocarcinoma, HPV 18- positive; CaSki, human cervical adeno-squamous carcinoma, HPV 16-positive; H8, human HPV E6/E7 immortalized cells. All the cell lines were obtained from the Cancer Center Laboratory of Shandong University, maintained in RPMI-1640 medium supplemented with 10\% foetal bovine serum (FBS, Gibco, Sydney, Australia) and were incubated in standard culture conditions (5\% $\mathrm{CO}_{2}, 37^{\circ} \mathrm{C}$ ). We also collected exfoliated cervical cells (as normal uterine cells, NUC) from the TCT samples of healthy women (females aged between 18 and 65), and found nothing abnormal in their physical examination, especially in the HPV and TCT tests.

\section{Transduction of the B7-H3-silencing or over-expressing plasmid}

To further clarify the roles of B7-H3 in cervical cancer, we transduced HeLa cells with the B7-H3 cDNA plasmid and transduced $\mathrm{SiHa}, \mathrm{CaSki}$, and H8 cells with the B7-H3 small hairpin RNA (shRNA) plasmid to target the expression of B7-H3. All plasmids were designed by GenePharma Co., Ltd. (Shanghai, China). The lentiviral vectors PGLVH1/ GFP-Puro and PGLV/GFP-1a-Puro were used to improve the transduction efficiency. After 5-7 days of selective culture with puromycin dihydrochloride (2 $\mu \mathrm{g} / \mathrm{ml}$; Amresco, Solon, OH, USA), the stably silenced or over-expressing cell lines were used to perform the subsequent experiments. For convenience, we abbreviated the knockdown and over-expressing cell lines as sh-B7-H3/pCMV-B7-H3, while the control cell lines are abbreviated as sh-NC/pCMV-NC.

\section{RNA preparation and real-time polymerase chain reaction ( $R T-P C R$ )}

Total RNA was extracted from the samples, as previously described[13]. The primers used in this study are as follows: B7-H3, F: 5'-CATCACACCCCA GAGAAGCC-3' and R: 5'-AGAGGGCCGTGCGGTT GGCA-3'; E7, F: 5'-AGTGTGACTCTACGCTTCGG-3' and R: 5'-TGTGCCCATTAACAGGTCTT-3'; Rb, F: 5'-CATCACACCCCAGAGAAGCC-3' and R: 5'-AGA GGGCCGTGCGGTTGGCA-3'; P16, F: 5'-GGGTTTTC GTGGTTCACATCC-3' and R: 5'-CTAGACGCTGGC TCCTCAGTA-3'; GAPDH, F: 5'-TGCACCACCTGCT TAGC-3' and R: 5'-AGAGGGCCGTGCGGTTGG CA-3'. sh-B7-H3, F: 5'-GUGCUGGAGAAAGAUCAA ATT-3' and R: UUUGAUCUUUCUCCAGCACTT-3'; 
sh-NC， F: 5'-UUCUCCGAACGUGUCACGUTT-3' and R: 5'-ACGUGACACGUUCGGAGAATT-3'. Expression of the reference gene GAPDH was used to normalize the mRNA expression of the other target genes. The data were quantified using the $2^{-\Delta \Delta C t}$ method.

\section{CCK-8 assay}

The cell survival rate was measured by a Cell Counting Kit-8 (CCK-8, Tongren, Shanghai, China) assay according to the manufacturer's instructions. In all, $2 \times 10^{3}$ cells were seeded into each well of a 96-well plate and were cultured in $100 \mu \mathrm{l}$ of RPMI-1640 supplemented with $10 \%$ FBS. At specific time points $(0,12,24,48,72 \mathrm{~h}), 10 \mu \mathrm{l}$ of CCK-8 reagent was added to every well, including the negative control, $4 \mathrm{~h}$ before the absorbance was measured at a wavelength of $450 \mathrm{~nm}$ using a microplate spectrophotometer (Infinite 2000; Tecan, Mannedorf, Switzerland).

\section{Flow cytometry}

After transduction, the distribution of cells in different stages of the cell cycle and apoptosis was analysed by flow cytometry (BD Biosciences, Franklin Lakes, NJ, USA), as previously described[13].

\section{Western Blotting}

Total protein was extracted from the samples, as previously described[13]. Primary antibodies used were anti-B7-H3 (1:1000, Abcam, Cambridge, UK, ab 105922), anti-P16 (1:1000, Abcam, ab 108349), anti-P21 (1:1000, Abcam, ab 109199), anti-E2F (1:1000, ProteinTech, Chicago, USA, 12171-1-AP), anti-PARP-1 (1:200, Santa Cruz Biotech, CA, USA, sc-8007), anti-Caspase-8 (1:200, Santa Cruz Biotech, sc-56070), anti-Bax (1:200, Santa Cruz Biotech, sc-7480), anti-Bcl-2 (1:200, Santa Cruz Biotech, sc-7382), anti-Bcl-xl (1:200, Santa Cruz Biotech, sc-8392), anti-E7 (1:1000, Abcam, ab 30731), anti-Rb (Cell Signaling Technology, Danvers, MA, USA, \#9309), and anti-GAPDH (1:5000, Cell Signaling Technology, \#2118). Secondary antibodies were anti-mouse and anti-rabbit IgG peroxidase conjugates (1:5000, Merck Millipore, MA, USA). The ImageQuant LAS 4000 system (GE Healthcare Life Sciences, Logan, UT, USA) was used to detect these proteins, and the results were quantified by ImageJ software $(\mathrm{NIH}$, Bethesda, MD, USA).

\section{Growth of B7-H3-silenced cells in athymic nude mouse}

Ten female athymic nude mice were randomly divided into two groups (5 mice/group) and were subcutaneously injected with $5 \times 10^{6} \mathrm{SiHa}$ cells transduced with either the sh-B7-H3 or the sh-NC plasmid. The tumour volume was measured every four days after tumour formation (approximately 6-10 days), and the tumour size was calculated according to the following formula: volume $=(\text { width })^{2 \times}$ length/2. Then, 48 days later, the xenografts were isolated from the mice, photographed and weighed. The growth curve of each tumour was then plotted.

\section{Statistical analysis}

Statistical analysis was performed using GraphPad Prism 5.01 software (GraphPad Software Inc., San Diego, CA, USA). All results were presented as the mean \pm the standard deviations (SD) of three independent experiments. Student's t-test, Chi-squared test $(n>5)$ or Yate's continuity corrected Chi-square test $(n \leq 5)$ was performed among the different groups. Finally, the Kaplan-Meier method and the log-rank test were used to analyse the survival data. $\mathrm{P}<0.05$ was considered statistically significant.

\section{Results}

\section{B7-H3 location in human cervical cancer tissues and cell line}

To determine the cellular location of $\mathrm{B} 7-\mathrm{H} 3$ and P16, we performed immunofluorescence (Figure 1A and $1 \mathrm{~B}$ ) and immunohistochemical staining (Figure $2 \mathrm{~A}$ and $2 \mathrm{~B}$ ). The results showed that $\mathrm{B} 7-\mathrm{H} 3$ was primarily located in the cytoplasm of cervical cancer cells and that P16 was mainly distributed within the cytoplasm and nucleus.

\section{The expression levels of $\mathrm{P} 16$ and $\mathrm{B} 7-\mathrm{H} 3$ in normal, CIN2-3, and cervical cancer tissues and their association with the clinicopathological characteristics}

We compared the expression of P16 and B7-H3 in normal, CIN2-3, and cervical cancer tissues. The data are presented in Table 1 . The expression of P16 and B7-H3 in normal cervical tissue was the same $(26.47 \%, 9 / 34)$, and in the CIN2-3 cervical tissue, the percentage of cases with positive B7-H3 expression was less than the percentage of cases with P16 expression $(17 / 25,68.00 \%$ vs. $20 / 25,80.00 \%)$; in cervical cancer tissue, the percentage of cases with B7-H3 expression was also low compared with P16 (37/60, 61.67\% vs. 52/60, 86.67\%). The relationship between P16 or B7-H3 expression and clinicopathological characteristics is summarized in Table 2. We found that the expression level of P16/B7-H3 was not correlated with age $(\mathrm{P}=0.8978 / 0.0657), \quad$ histology $\quad(\mathrm{P}=0.1093 / 0.2629)$, tumour differentiation $(\mathrm{P}=0.9392 / 0.7286)$, clinical stage $(P=0.5209 / 0.8224)$, tumour size $(P=0.6580 /$ 0.5181), lymph vascular space involvement (LVSI, $\mathrm{P}=0.6196 / 0.1735$ ), or lymph node metastasis (LNM, 
A

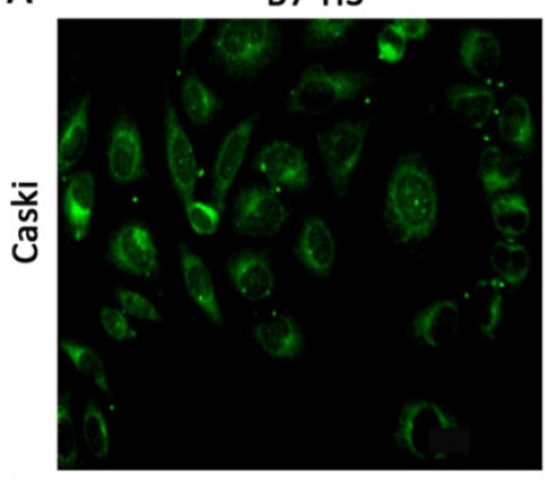

B

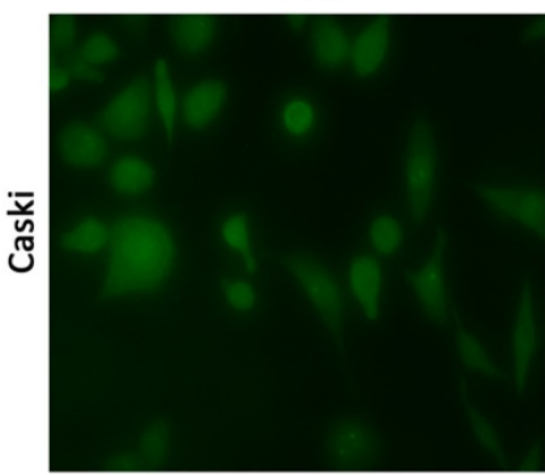

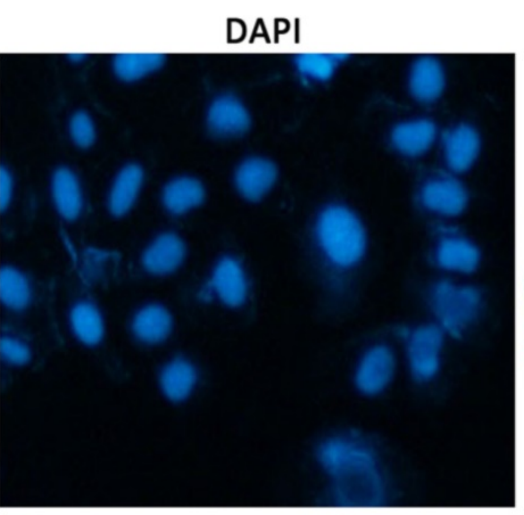

DAPI

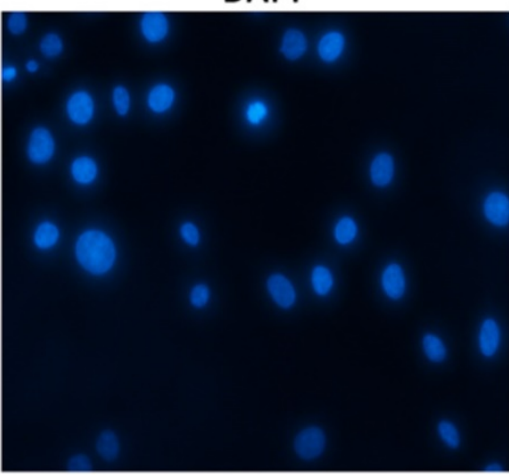

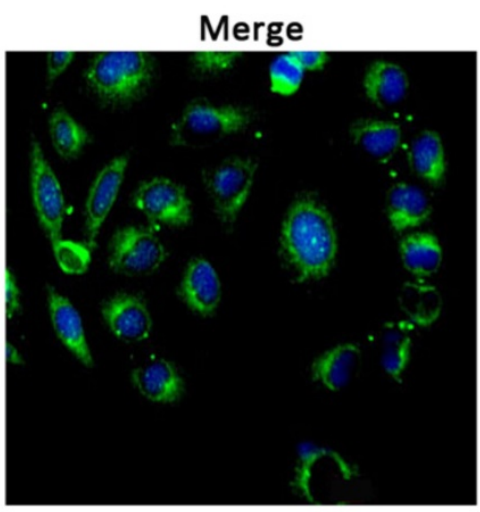

Merge

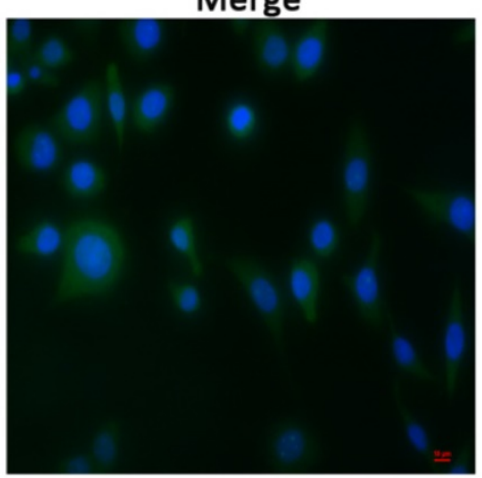

Figure 1. Subcellular distribution or localization of B7-H3/P16 in CaSki cells (x100) CaSki cells were stained for B7-H3, which was detected in the cytoplasm, and with DAPI, which labelled the nucleus; P16 was distributed in both the cytoplasm and the nucleus.

$\mathrm{P}=0.3427 / 0.8458)$. However, a significant association was detected between the positive expression of P16/B7-H3 and deep stromal invasion (DSI, $\mathrm{P}<0.0001 / \mathrm{P}=0.0013$ ).

Table 1. Detection of $\mathrm{P} 16$ and $\mathrm{B} 7-\mathrm{H} 3$ in normal cervix, $\mathrm{CIN}$ and cervical cancer tissue.

\begin{tabular}{lll}
\hline Pathology diagnosis & P16 & B7-H3 \\
\hline Squamous epithelia of & No evidence of CIN & No evidence of CIN \\
cervix-negative for CIN/cervical & $5 / 19$ & $4 / 19$ \\
cancer & Adjacent to & Adjacent to \\
& CIN/cancer 4/15 & CIN/cancer 5/15 \\
& TOTAL 9/34 (26.47\%) & TOTAL 9/34 $(26.47 \%)$ \\
CIN2-3 & 20/25 (80.00\%) & $17 / 25(68.00 \%)$ \\
Cervical cancer & $52 / 60(86.67 \%)$ & $37 / 60(61.67 \%)$ \\
\hline
\end{tabular}

$\mathrm{CIN}$, cervical intraepithelial neoplasia.

\section{Expression of B7-H3 is correlated with poor survival in cervical cancer patients}

Herein, we collected the survival data from cervical cancer patients whose tumours expressed P16 and B7-H3. Decreased disease-free survival (DFS) time was observed in cervical cancer patients with B7-H3-positive tumours compared with those with B7-H3-negative tumours (Figure 3B, log rank $\mathrm{P}=0.0317)$. However, no significant association was found between the expression of P16 and the DFS time (Figure 3A, log rank $\mathrm{P}=0.3486$ ).
Table 2. Association between $\mathrm{P} 16 / \mathrm{B} 7-\mathrm{H} 3$ expression and clinicopathological factors.

\begin{tabular}{|c|c|c|c|c|c|c|c|}
\hline \multirow[t]{2}{*}{ Variables } & \multirow[t]{2}{*}{ No. } & \multicolumn{3}{|c|}{ Expression of P16 } & \multicolumn{3}{|c|}{ Expression of B7-H3 } \\
\hline & & Negative & Positive & $\mathrm{P}$-value & Negative & Positive & P-value \\
\hline Age & & & & 0.8978 & & & 0.0657 \\
\hline$\leq 45$ & 35 & 4 & 31 & & 10 & 25 & \\
\hline$>45$ & 25 & 4 & 21 & & 13 & 12 & \\
\hline Histology & & & & 0.1093 & & & 0.2629 \\
\hline SCC & 52 & 5 & 47 & & 18 & 34 & \\
\hline Adenocarcinoma & 8 & 3 & 5 & & 5 & 3 & \\
\hline Clinical Stage & & & & 0.5209 & & & 0.8224 \\
\hline Stage I & 35 & 6 & 29 & & 13 & 22 & \\
\hline Stage II & 25 & 2 & 23 & & 10 & 15 & \\
\hline Differentation & & & & 0.9392 & & & 0.7286 \\
\hline Low & 27 & 4 & 23 & & 11 & 16 & \\
\hline Moderate/High & 33 & 4 & 29 & & 12 & 21 & \\
\hline Tumor Size & & & & 0.6580 & & & 0.5181 \\
\hline$<4 \mathrm{~cm}$ & 37 & 6 & 31 & & 13 & 24 & \\
\hline$\geq 4 \mathrm{~cm}$ & 23 & 2 & 21 & & 10 & 13 & \\
\hline LNM & & & & 0.3427 & & & 0.8458 \\
\hline Negative & 49 & 8 & 41 & & 19 & 30 & \\
\hline Positive & 11 & 0 & 11 & & 4 & 7 & \\
\hline LVSI & & & & 0.6196 & & & 0.1735 \\
\hline Negative & 55 & 33 & 17 & & 23 & 32 & \\
\hline Positive & 5 & 8 & 2 & & 0 & 5 & \\
\hline DSI & & & & $<0.0001^{*}$ & & & $0.0013^{*}$ \\
\hline$<1 / 2$ & 16 & 8 & 8 & & 12 & 4 & \\
\hline$\geq 1 / 2$ & 44 & 0 & 44 & & 11 & 33 & \\
\hline
\end{tabular}

SCC, squamous cell carcinoma; LNM, lymph node metastasis; LVSI, lymph vascular space involvement; DSI, deep stromal invasion. *Statistically significantly value. 

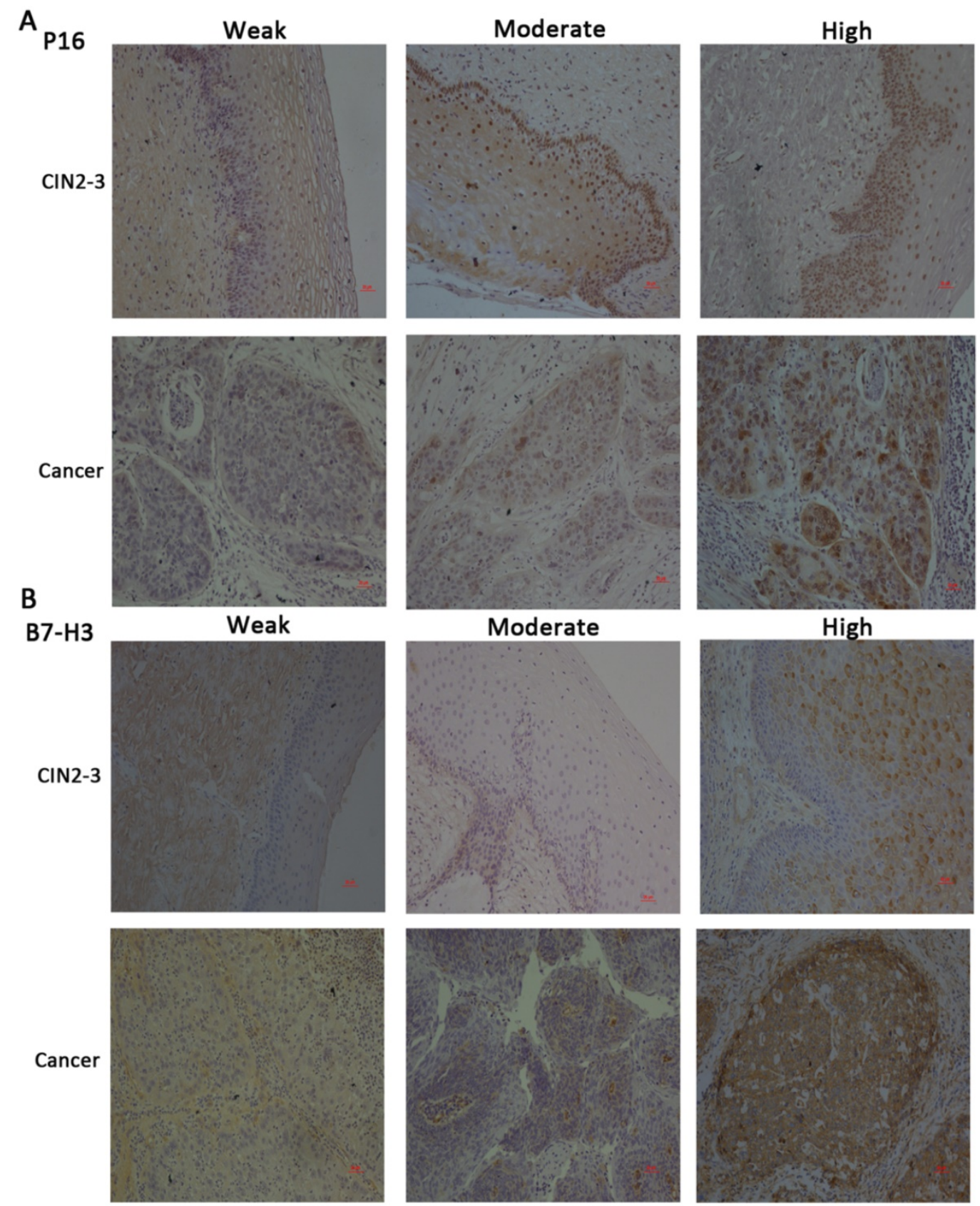

Figure 2. Immunohistochemical staining for P16 and B7-H3 in CIN2-3 and cervical cancer tissues and representative images of weak, moderate, and strong staining ( 100 ).
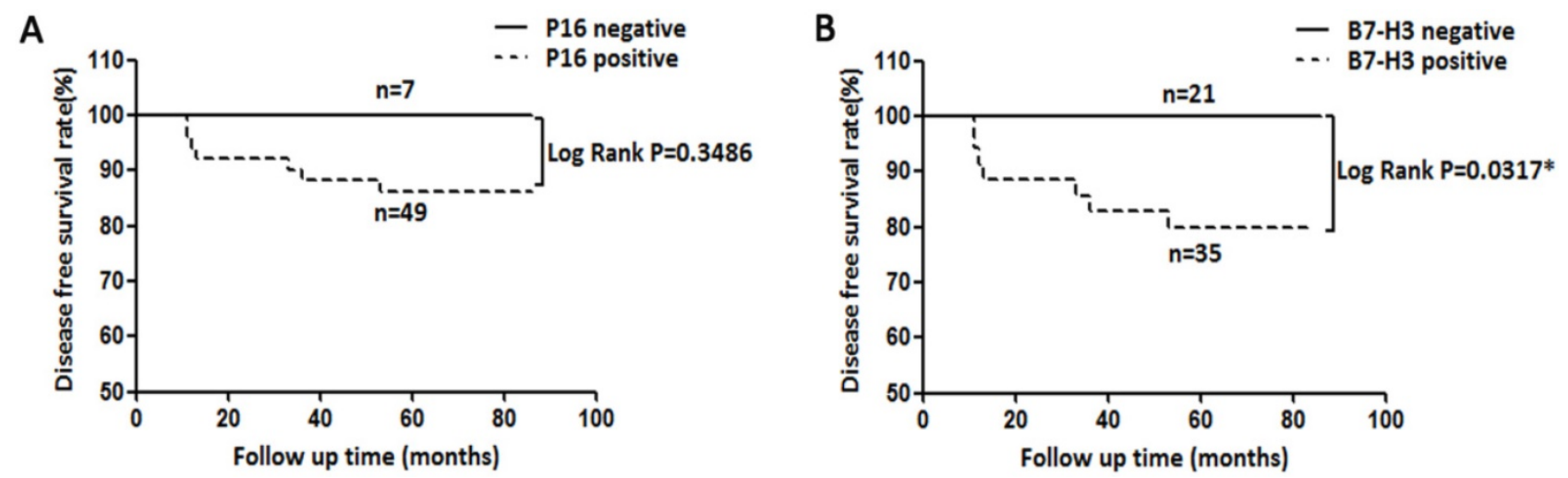

Figure 3. Kaplan-Meier disease-free survival (DFS) curve of cervical cancer patients and the correlation of DFS with P16 expression (A) and B7-H3 expression (B). 
Serum B7-H3

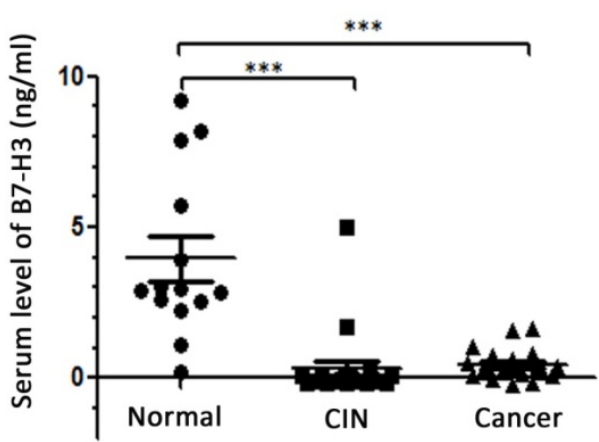

Figure 4. Distribution of serum $\mathrm{B} 7-\mathrm{H} 3$ in healthy women, cervical intraepithelial neoplasia $(\mathrm{CIN})$ patients and cervical cancer patients. ${ }^{*} * \mathrm{P}<0.001$ compared with healthy women.

\section{Expression of serum B7-H3 in CIN and cervical cancer patients}

To determine the expression of $\mathrm{B} 7-\mathrm{H} 3$ in the blood, ELISA was performed to detect the levels of B7-H3 in serum samples from 15 healthy women, 20 patients with CIN and 20 patients with cervical cancer. The results (Figure 4) suggested that the level of B7-H3 in the serum of CIN patients was lower than that in the serum of healthy women $(0.302 \pm 0.263 \mathrm{vs}$. $3.952 \pm 0.732 \mathrm{ng} / \mathrm{ml}, \mathrm{P}<0.0001)$; the level of $\mathrm{B} 7-\mathrm{H} 3$ was also lower in the serum of cervical cancer patients compared with the corresponding level in the serum of healthy women $(0.443 \pm 0.108$ vs. $3.952 \pm 0.732 \mathrm{ng} / \mathrm{ml}$, $\mathrm{P}<0.0001)$. No significant difference was observed in the serum levels of B7-H3 between CIN and cervical cancer patients $(\mathrm{P}=0.6171)$.

\section{B7-H3 expression in human cervical cancer cell lines}

We detected the protein level of $\mathrm{B} 7-\mathrm{H} 3$ in various cervical cancer cell lines including $\mathrm{SiHa}, \mathrm{HeLa}, \mathrm{CaSki}$, and $\mathrm{H} 8$ as well as in normal uterine cells (NUC) by western blot. As shown in Figure 5A, B7-H3 expression levels in $\mathrm{SiHa}, \mathrm{CaSki}$, and $\mathrm{H} 8$ cells were significantly higher than the level in NUC, while the B7-H3 level was the lowest in HeLa cells. As a consequence, $\mathrm{SiHa}, \mathrm{CaSki}$, and $\mathrm{H} 8$ cells were transduced with the B7-H3 sh-RNA plasmid while HeLa cells were transduced with the B7-H3 cDNA plasmid. Compared with their respective control groups, the efficiency of silencing or over-expression in these cell lines was at least $50 \%$ at the mRNA levels (Figure 5C-F).

\section{Effects of B7-H3 silencing and over-expression on the expression of E7, Rb, and P 16 mRNA}

To investigate the influence of $\mathrm{B} 7-\mathrm{H} 3$ on the expression of $\mathrm{E7}, \mathrm{Rb}$, and P16 mRNA, we performed RT-PCR. Compared with their respective control groups, the silencing of $\mathrm{B} 7-\mathrm{H} 3$ in $\mathrm{SiHa}$, CaSki, and $\mathrm{H} 8$ cells resulted in a decline in E7 mRNA and an increase in $\mathrm{Rb}$ mRNA (except for E7 mRNA in CaSki cells), while the over-expression of B7-H3 in HeLa cells led to the opposite effect. Moreover, the expression of P16 mRNA also declined when B7-H3 was silenced in $\mathrm{SiHa}$ and CaSki cells (Figure 5C-F). The results revealed no difference between the untreated cells (blank control) and the sh-NC groups (Figure 5C-F).

\section{B7-H3 induces cell proliferation}

The effect of B7-H3 on cervical cancer cell viability was measured by CCK- 8 assay. As seen in Figure 6A, cell viability was weakened in the sh-B7-H3 groups of SiHa and CaSki cells at 12 and 24 hours post-transduction, respectively, and compared with that of the control group, in the HeLa pCMV-B7-H3 group, cell viability began to increase at $48 \mathrm{~h}$ post-transduction. In addition, flow cytometry was performed to examine whether B7-H3 could affect cell cycle distribution. As shown in Figure 6B and $6 \mathrm{C}$, compared with the control groups, $\mathrm{SiHa}$, CaSki, and $\mathrm{H} 8$ cells transduced with sh-B7-H3 were arrested in G0/G1 phase, and HeLa cells transduced with pCMV-B7-H3 were more likely to be accelerated in $S$ phase.

\section{B7-H3 inhibits cell apoptosis}

Flow cytometry was used to investigate the apoptotic effect of B7-H3. As shown in Figure 7A and 7B, the silencing of B7-H3 in SiHa, CaSki, and $\mathrm{H} 8$ cells led to an increase in the number of cells in late apoptosis (PI+/Annexin+), while the over-expression of B7-H3 in HeLa cells led to a decrease in the number of cells in early apoptosis (7AAD-/ Annexin+).

\section{The effect of B7-H3 on the expression of cell cycle- and apoptosis-related proteins}

As shown in Figure 8 and Figure 9, compared with their respective control groups, the efficiency of B7-H3 silencing or over-expression in these cell lines was at least $50 \%$ at the protein levels. The expression of the cell cycle-related proteins E2F, P21, and P16 was decreased in the sh-B7-H3 groups of $\mathrm{SiHa}, \mathrm{CaSki}$, and H8 cells compared with their respective control groups. Moreover, the apoptosis-related proteins PARP-1, Caspase-8, and Bax were upregulated in these cell lines, while the anti-apoptotic proteins Bcl-2 and Bcl-xl were downregulated compared with the control cells (Figure 8A and 8B; Figure 9A). In the pCMV-B7-H3 group of HeLa cells, the results showed the opposite tendency (Figure 9B). Protein E7 and Rb showed the same trend in terms of mRNA expression (Figure 8A and 8B; Figure 9A and 9B). Note that not all cell lines, but at least two, showed statistically significant differences in terms of the western blot results. 
A

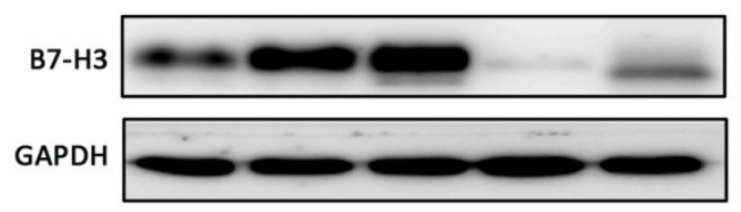

C

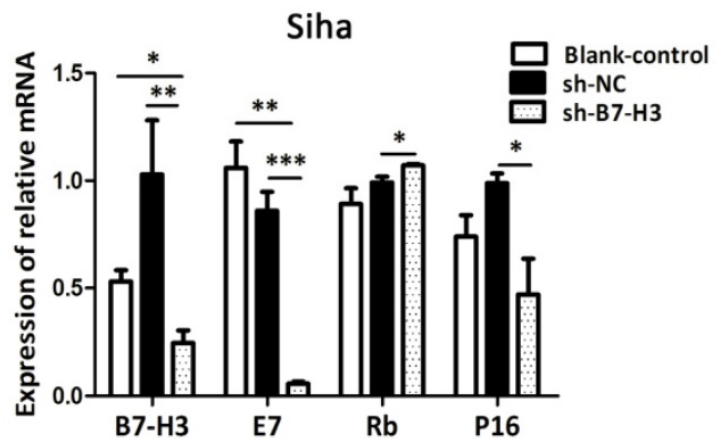

B

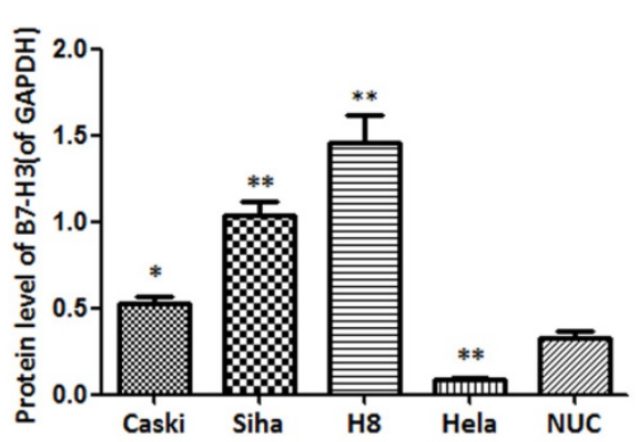

E

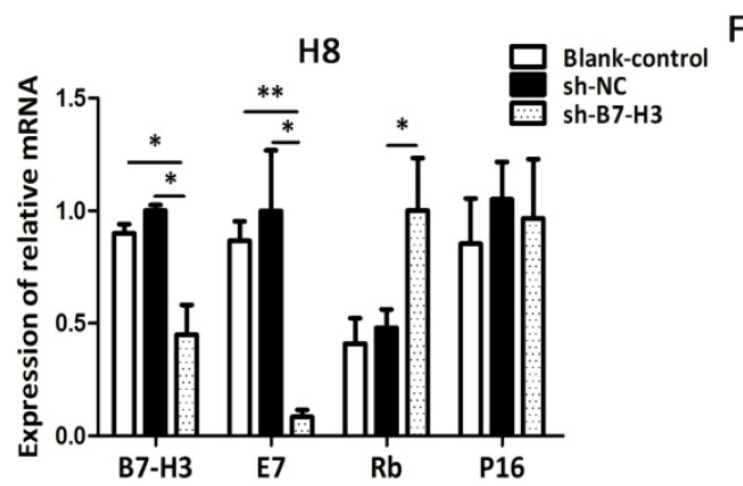

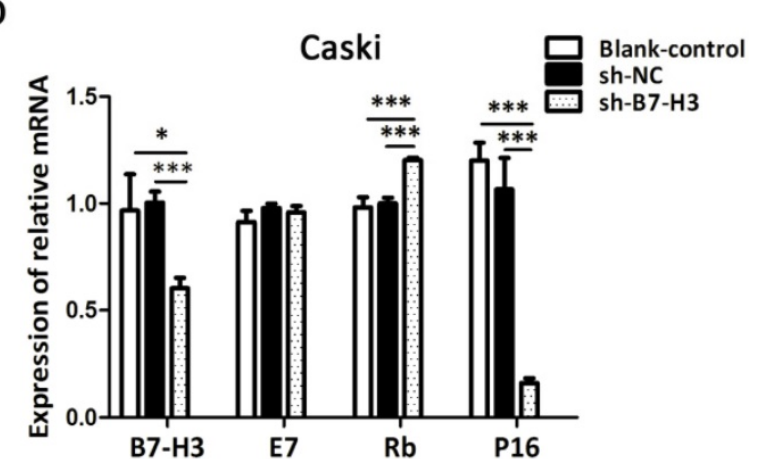

F

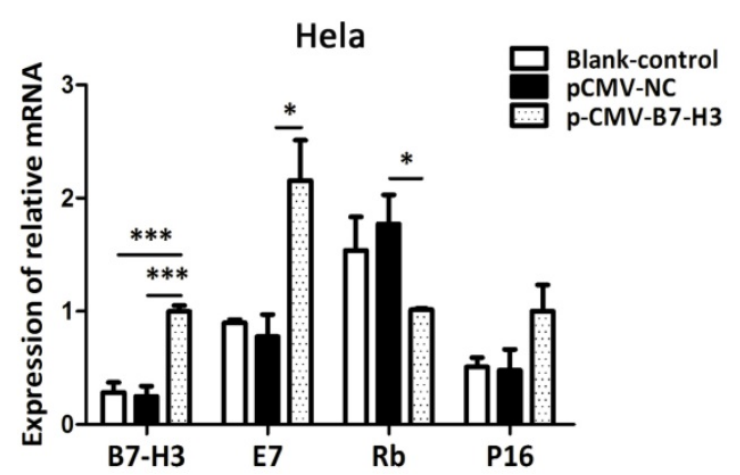

Figure 5. B7-H3 expression in cervical cancer cell lines and the effects of B7-H3 silencing and over-expression on E7/Rb/P16 mRNA. (A) The protein levels of B7-H3 were determined by western blotting in $\mathrm{CaSki}, \mathrm{SiHa}, \mathrm{H} 8$, and $\mathrm{HeLa}$, cells and in normal uterine cervix (NUC) cells. (B) Quantifications of the protein expression levels as shown in $\mathrm{A}$. $* \mathrm{P}<0.05$, **P<0.01 compared with NUC cells. (C, D, E, and F) RT-PCR was performed in order to identify the mRNA levels of B7-H3, E7, Rb and P16 after B7-H3 was silenced in Siha, CaSki, and $\mathrm{H} 8$ cells and after $\mathrm{B} 7-\mathrm{H} 3$ was over-expressed in HeLa cells. $* \mathrm{P}<0.05$, $* * \mathrm{P}<0.01$, $* * * \mathrm{P}<0.001$ compared with the control groups.

\section{Knockdown of B7-H3 suppresses the growth of cervical carcinoma in vivo}

To determine whether the silencing of B7-H3 in cervical cancer could reduce tumour growth in vivo, SiHa cells transduced with control plasmid and sh-B7-H3 were injected subcutaneously into athymic nude mice. The tumour volumes were then measured for 48 days. As seen in Figure 10A and 10C, sh-B7-H3 tumours grew at a slower rate compared with tumours in the control group after day $40(\mathrm{P}=0.0418)$. Additionally, the average size and weight of sh-B7-H3 tumours were also smaller and lighter than in the control groups (Figure 10B and 10D, $\mathrm{P}=0.0179$ ). All these data suggested that the inhibition of $\mathrm{B} 7-\mathrm{H} 3$ in
SiHa cervical cancer cells suppressed tumour growth in these nude mice.

\section{Discussion}

Due to the strict requirements of clinical trials for the cervical cancer vaccine in China, the bivalent vaccine Cervarix (mainly for HPV 16 and HPV 18), which is manufactured by GlaxoSmithKline (GSK) $\mathrm{Plc}$, was not available to young Chinese women until October of last year. This delayed vaccination resulted in a large number of CIN and cervical cancer cases in China. Other developing countries are faced with the same problems. Thus, additional work is required for an accurate diagnosis and effective treatment for patients with CIN and cervical cancer. 
The defects in the immune microenvironment of the cervix may contribute to the occurrence and development of CIN and cervical cancer[14-16]. The novel immunoregulatory members of the B7-CD28 family, programmed death-1 (PD-1, CD279) and programmed death-ligand 1 (PD-L1, CD274), have been demonstrated to negatively regulate cervical cell-mediated immunity to HPV infection and have been shown to contribute to the progression of high-risk HPV-related CIN[17]. The most recent additions to the B7 family are B7-H3 (CD276) and B7-H4 (B7S1, B7x, VTCN 1)[18, 19]. In a previous study[13], we reported the negative roles of B7-H4 in the proliferation, apoptosis, migration and invasiveness of cervical cancer cells as well as the diagnostic value of serum B7-H4. In addition, an increasing number of reports has suggested that B7-H3 may exert effects that are similar to those of B7-H4[8, 20], which prompted us to perform this study. Many studies have reported that P16 serves as a useful additional marker for the interpretation of problematic TCT and that its assessment reduces uncertainty during the evaluation of suspicious biopsies of the uterine cervix in patients with CIN and cervical cancer[21-24]. Consequently, we used P16 as a reference.
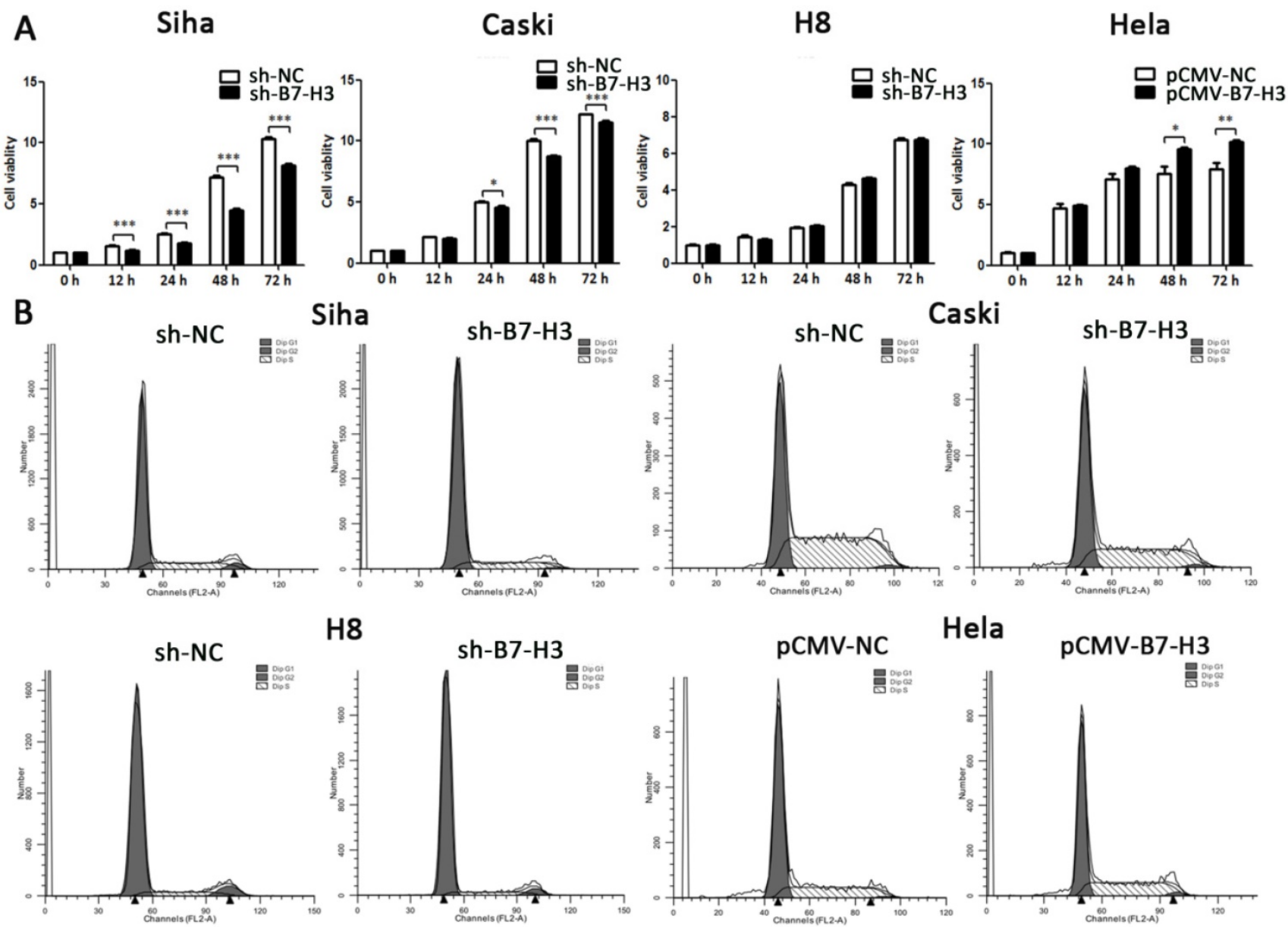

C
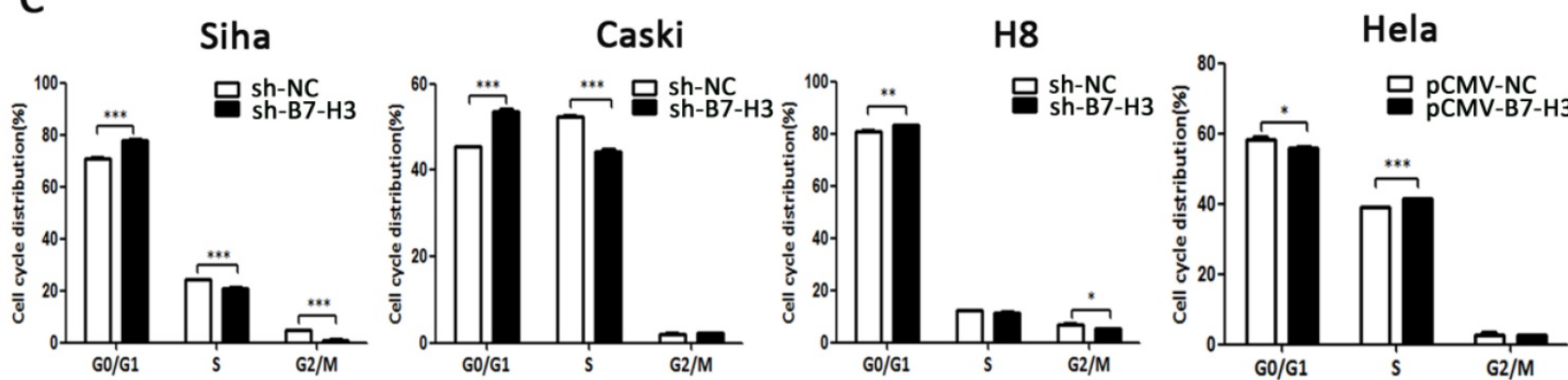

Figure 6. The effect of B7-H3 on cell viability and cell cycle distribution. (A) After sh-B7-H3 or PCMV-B7-H3 transduction in SiHa, CaSki, H8, and HeLa cells for 0, $12,24,48$, and $72 \mathrm{~h}$, cell viability was determined by CCK-8 assay. (B) Cell cycle distributions of sh-B7-H3- or PCMV-B7-H3-transduced cells and their control groups were identified by flow cytometry. (C) Cell cycle phase distribution was expressed as a percentage of total cells as shown in $\mathrm{C}$. *P $<0.05$, $* * \mathrm{P}<0.01$, $* * * \mathrm{P}<0.001$ compared with the control groups. 

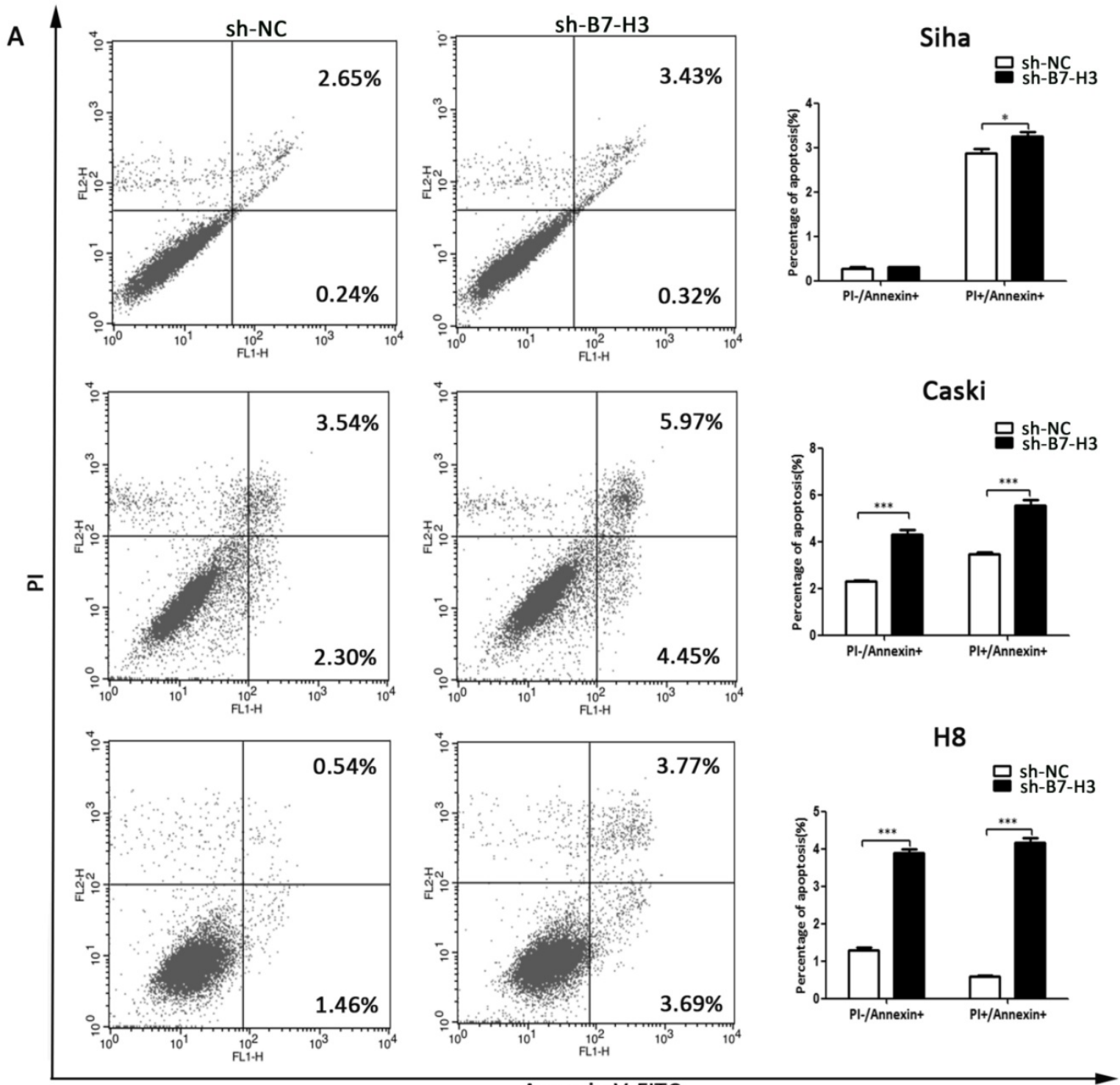

B
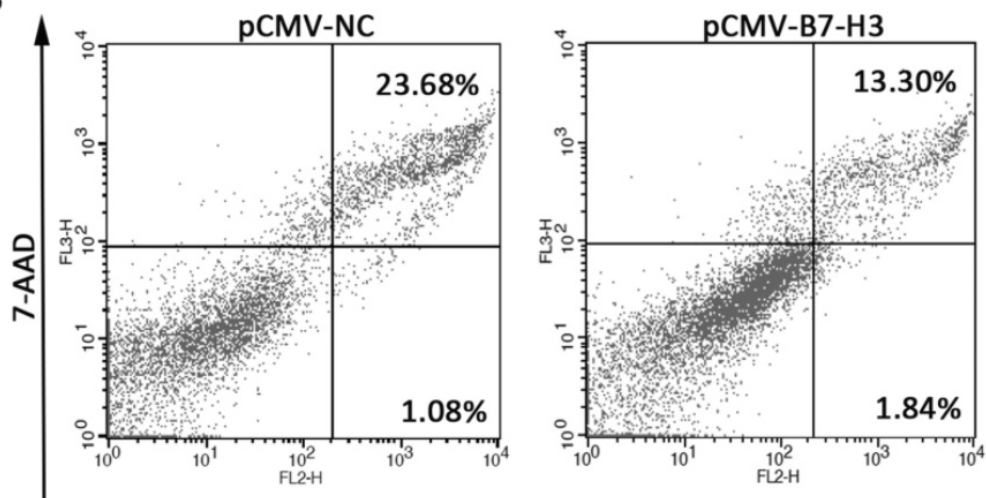

Hela

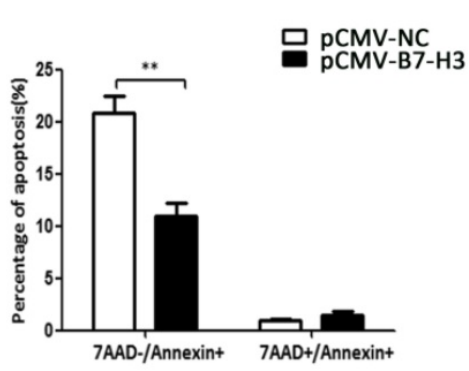

Figure 7. The effect of B7-H3 on cell apoptosis. (A, B and C) The knockdown of B7-H3 by sh-RNA induced early and late apoptosis in SiHa, CaSki, and H8 cells. (D) Over-expression of $\mathrm{B} 7-\mathrm{H} 3$ in HeLa cells decreased the number of cells in early apoptosis. Figures that show the quantifications are all on the right side. $* \mathrm{P}<0.05$, $* * P<0.01$, $* * * \mathrm{P}<0.001$ compared with the control groups. 


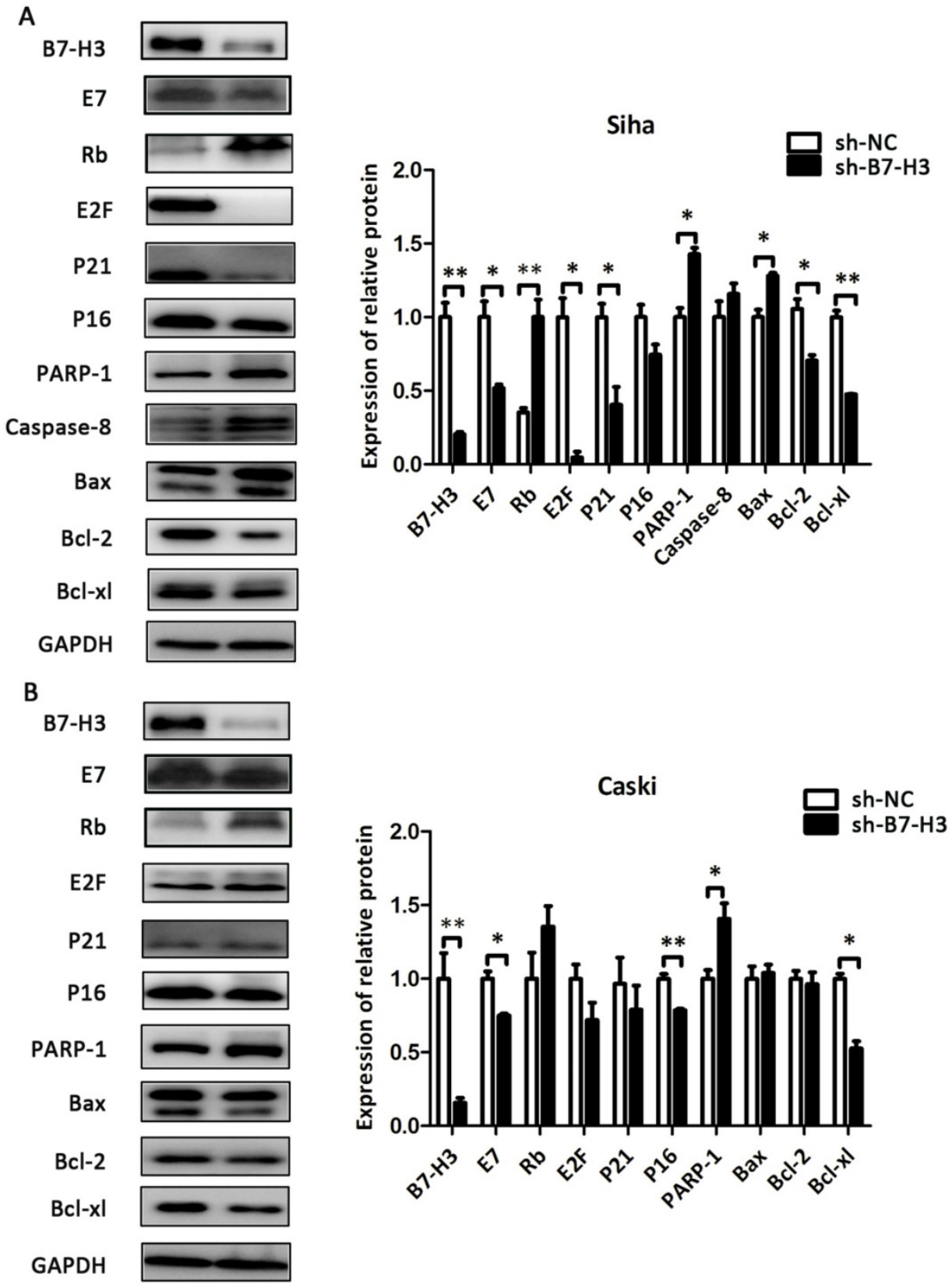

Figure 8. The effect of $\mathrm{B} 7-\mathrm{H} 3$ on the expression of cell cycle- and apoptosis-related proteins in $\mathrm{SiHa}$ and $\mathrm{CaSki}$ cells. After sh-B7-H3 transduction, the protein expression levels of B7-H3, E7, Rb, E2F, P21 P16, PARP-1, Caspase-8, Bax, Bcl-2, and Bcl-xl in SiHa and CaSki cells were determined and analysed by western blot. *P<0.05, **P<0.01 compared with the control groups.

In the present study, we found that the expression of B7-H3 in CIN and cervical cancer tissues was higher than in the normal cervix and in tissues adjacent to CIN and cervical cancer, which was consistent with P16 expression in these tissues (Table 1). After the expression of B7-H3 was analysed in the context of the clinical variables, we found that both B7-H3 and P16 were significantly associated with deep stromal invasion by cervical cancer (Table 2). The survival analysis indicated that the level of B7-H3 expression has the potential to be a useful prognostic marker for cervical cancer patients if P16 data are unavailable, since the results were consistent with several studies of human oesophageal cancer, osteosarcoma, and gastric carcinoma [25-27]. Moreover, we detected the expression of B7-H3 in the serum of CIN and cervical cancer patients, and found that the serum level of B7-H3 in CIN and cervical cancer patients was lower than that in healthy women, which was contrary to serum B7-H4 as described previously [13]. Two primary reasons may account for this difference: one is that the B7-H3 in the serum samples from CIN and cervical cancer patients is a different isoform than that present in the serum of normal controls $[3,18,28]$, and the other is that serum B7-H3 in CIN and cervical cancer patients might 
combine with $\mathrm{T}$ cell receptors in the blood, which would provide inhibitory signals[29-32]. Then we detected the expression of $\mathrm{B} 7-\mathrm{H} 3$ in cervical cancer cell lines and TCT samples, and the results showed that $\mathrm{B} 7-\mathrm{H} 3$ expression was higher in three of the four cervical cancer cell lines than in NUC. After the expression of B7-H3 was silenced in SiHa, CaSki, and $\mathrm{H} 8$ cells, we found that the mRNA expression of the HPV oncogene E7 declined and that the mRNA of the suppressor gene $\mathrm{Rb}$ increased with a reduction in B7-H3. When we over-expressed B7-H3 in HeLa cells, the level of E7 mRNA increased while the level of Rb mRNA declined; the protein levels of E7 and $\mathrm{Rb}$ showed the same trend. The E7/Rb pathway plays key roles in the carcinogenic process associated with high-risk HPV infection[33]. The CCK-8 and flow cytometry assays that followed demonstrated that B7-H3 could accelerate the cell cycle and inhibit apoptosis, which is consistent with results of the study by Lunjun Chen et al in human oesophageal cancer[25]. In addition, the tumour formation experiment in nude mice also demonstrated the tumourigenic potential of $\mathrm{B} 7-\mathrm{H} 3$. These changes were mainly due to the regulation of E2F, P21, P16, PARP-1, Caspase-8, Bax, Bcl-2 and Bcl-xl, as shown by the western blot results.
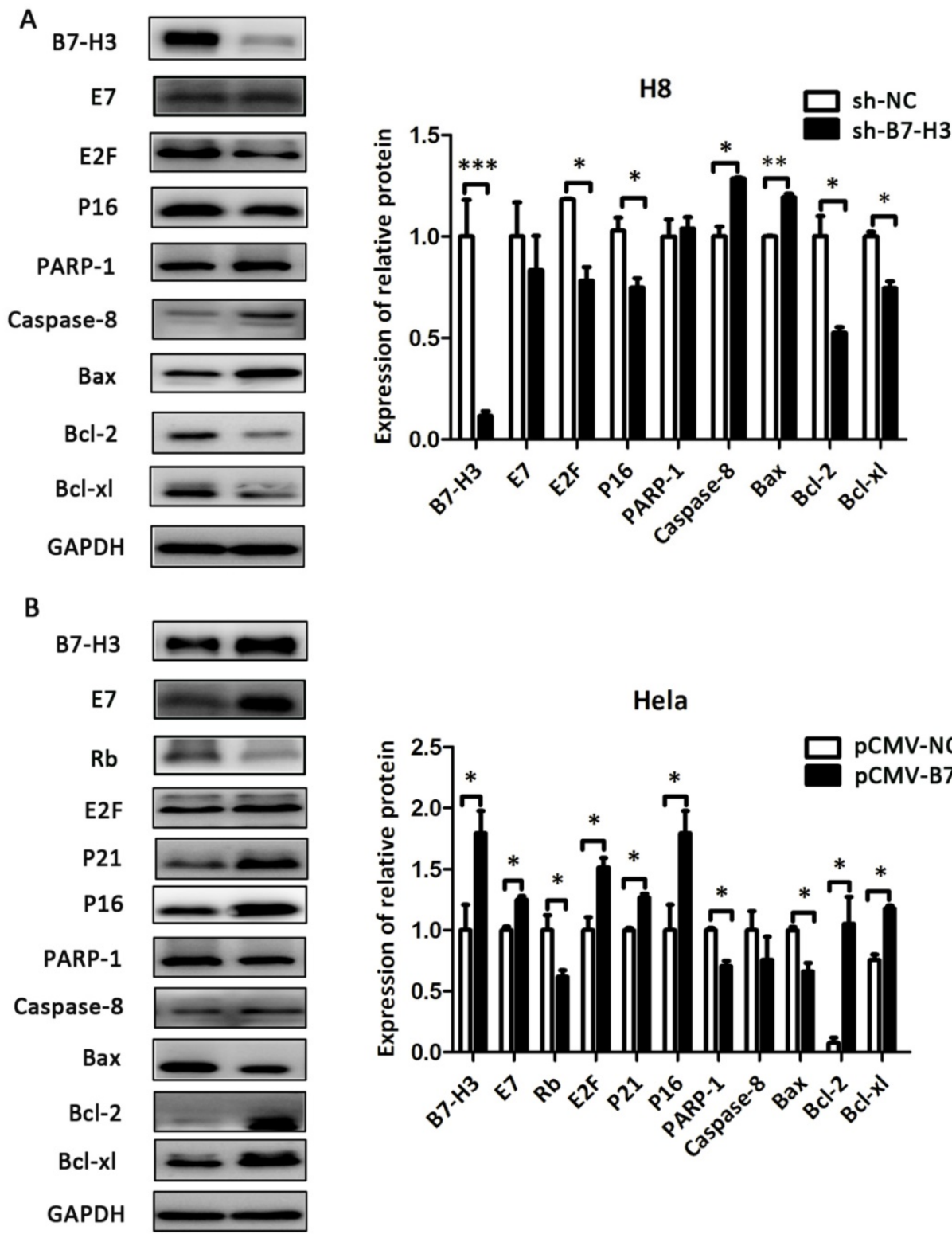

Figure 9. The effect of $\mathrm{B} 7-\mathrm{H} 3$ on the expression of cell cycle- and apoptosis-related proteins in $\mathrm{H} 8$ and $\mathrm{HeLa}$ cells. After sh-B7-H3 transduction in $\mathrm{H} 8$ cells and pCMV-B7-H3 transduction in HeLa cells, the protein expression levels of B7-H3, E7, Rb, E2F, P21 P16, PARP-1, Caspase-8, Bax, Bcl-2, and Bcl-xl were determined and analysed by western blot. $* \mathrm{P}<0.05, * * \mathrm{P}<0.01, * * * \mathrm{P}<0.001$ compared with the control groups. 

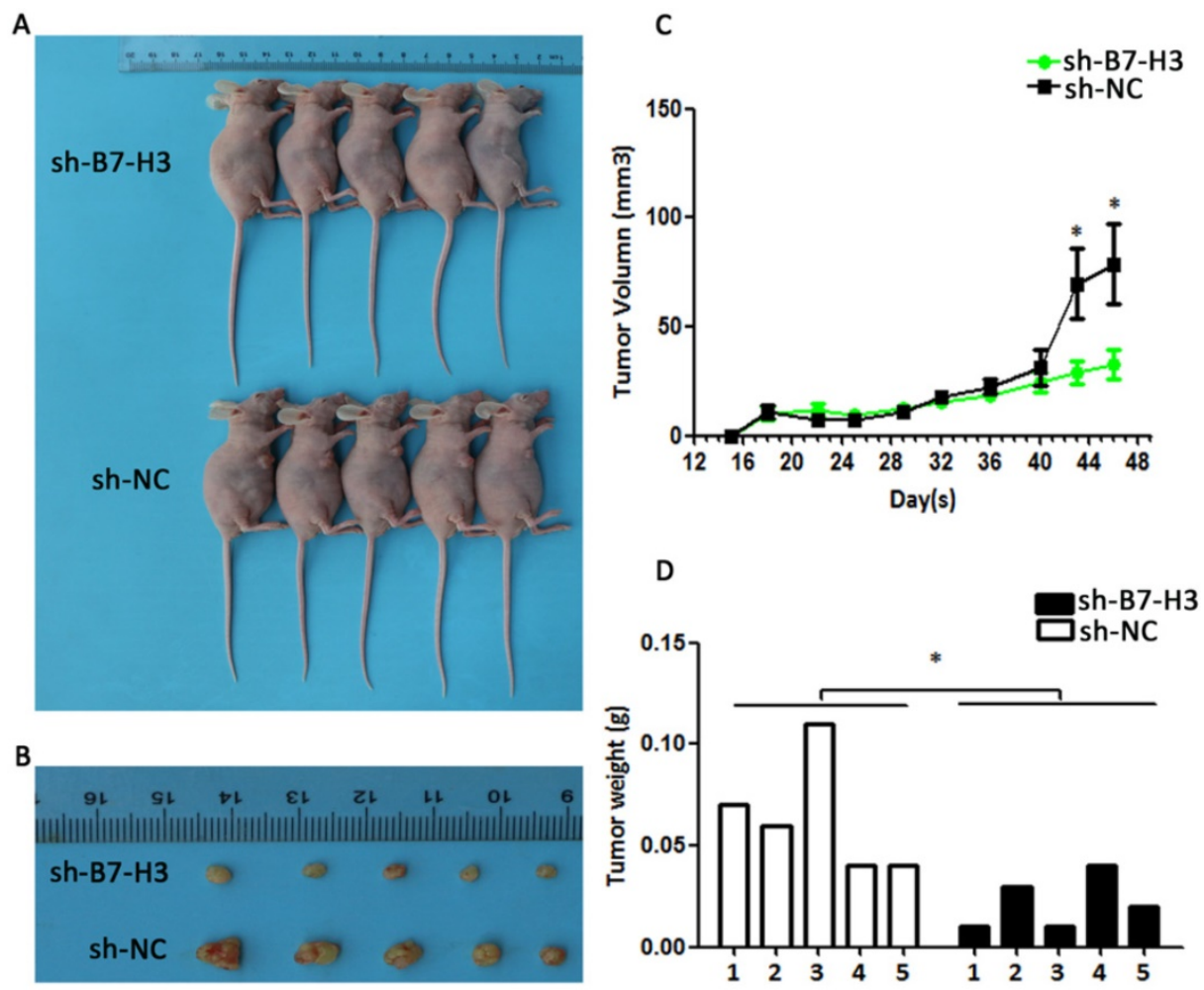

Figure 10. Effect of B7-H3 sh-RNA on tumour growth in vivo. SiHa cells transduced with sh-B7-H3 were subcutaneously injected into nude mice. (A and C) Tumour volumes were measured for 48 days. (B and D) At day 48, the nude mice were sacrificed and the tumours were weighed. $* \mathrm{P}<0.05$ compared with the control groups.

Our study still had several limitations, such as the small number of clinical patients, and we used only SiHa cells in the tumour formation assay in nude mice due to the lab conditions.

In summary, our present study suggested that the co-stimulatory molecule B7-H3 was involved in human CIN and cervical cancer progression. Higher expression of $\mathrm{B} 7-\mathrm{H} 3$ in cervical cancer tissue was significantly associated with tumour invasion depth and poor survival. The silencing or over-expression of B7-H3 in cervical cancer cell lines showed that this molecule was involved in cell proliferation and apoptosis, which might have occurred through its effects on the $E 7 / \mathrm{Rb}$ pathway. All the results indicated that $\mathrm{B} 7-\mathrm{H} 3$ has the potential to be a useful prognostic marker for cervical cancer patients, and thus more efforts are needed for the development of therapeutic approaches that target B7-H3.

\section{Acknowledgements}

The study was conducted at Qilu Hospital, Shandong University and was supported by the National Key R\&D Program of China (2016YF C1302900), the National Natural Science Foundation of China (NSFC, 81572559), the Key Research Project of Shandong Province (2017CXGC1210), the Science and Technology Development Plan of Shandong Province (2014GGH218029) and the National Science and Technology Project of China (2015BAI13B05).

\section{Competing Interests}

The authors have declared that no competing interest exists.

\section{References}

1. Torre LA, Bray F, Siegel RL, Ferlay J, Lortet-Tieulent J, Jemal A. Global cancer statistics, 2012. CA: a cancer journal for clinicians. 2015; 65: 87-108.

2. Chen W, Zheng R, Baade PD, Zhang S, Zeng H, Bray F, et al. Cancer statistics in China, 2015. CA: a cancer journal for clinicians. 2016; 66: 115-32.

3. Ni L, Dong C. New checkpoints in cancer immunotherapy. Immunological reviews. 2017; 276: 52-65.

4. Yin SJ, Wang WJ, Zhang JY. Expression of B7-H3 in cancer tissue during osteosarcoma progression in nude mice. Genetics and molecular research : GMR. 2015; 14: 14253-61.

5. Sun J, Guo Y, Li X, Zhang Y, Gu L, Wu P, et al. B7-H3 expression in breast cancer and upregulation of VEGF through gene silence. OncoTargets and Therapy. 2014: 1979.

6. Qin X, Zhang H, Ye D, Dai B, Zhu Y, Shi G. B7-H3 is a new cancer-specific endothelial marker in clear cell renal cell carcinoma. Onco Targets Ther. 2013; 6: 1667-73.

7. Sun Y, Wang Y, Zhao J, Gu M, Giscombe R, Lefvert AK, et al. B7-H3 and B7-H4 expression in non-small-cell lung cancer. Lung cancer. 2006; 53: 143-51.

8. Wang L, Cao NN, Wang S, Man HW, Li PF, Shan BE. Roles of coinhibitory molecules B7-H3 and B7-H4 in esophageal squamous cell carcinoma. Tumour biology : the journal of the International Society for Oncodevelopmental Biology and Medicine. 2016; 37: 2961-71.

9. Chen JT, Chen $\mathrm{CH}, \mathrm{Ku} \mathrm{KL}, \mathrm{Hsiao} \mathrm{M}$, Chiang CP, Hsu TL, et al. Glycoprotein B7-H3 overexpression and aberrant glycosylation in oral cancer and immune response. Proceedings of the National Academy of Sciences of the United States of America. 2015; 112: 13057-62.

10. Loos M, Hedderich DM, Ottenhausen M, Giese NA, Laschinger M, Esposito I, et al. Expression of the costimulatory molecule B7-H3 is associated with prolonged survival in human pancreatic cancer. BMC cancer. 2009; 9: 463.

11. Ingebrigtsen VA, Boye K Fau - Tekle C, Tekle C Fau - Nesland JM, Nesland Jm Fau - Flatmark K, Flatmark K Fau - Fodstad O, Fodstad O. B7-H3 expression in colorectal cancer: nuclear localization strongly predicts poor outcome in colon cancer. International journal of cancer. 2012; 131: 2528-36.

12. Mutch DG. The new FIGO staging system for cancers of the vulva, cervix, endometrium and sarcomas. Gynecologic oncology. 2009; 115: 325-8.

13. Han S, Li Y, Zhang J, Liu L, Chen Q, Qian Q, et al. Roles of immune inhibitory molecule B7-H4 in cervical cancer. Oncology reports. 2017; 37: 2308-16. 
14. Piersma SJ. Immunosuppressive tumor microenvironment in cervical cancer patients. Cancer microenvironment : official journal of the International Cancer Microenvironment Society. 2011; 4: 361-75.

15. Bontkes HJ, de Gruijl TD, van den Muysenberg AJ, Verheijen RH, Stukart MJ, Meijer CJ, et al. Human papillomavirus type 16 E6/E7-specific cytotoxic T lymphocytes in women with cervical neoplasia. International journal of cancer. 2000; 88: 92-8.

16. Nimako M, Fiander AN, Wilkinson GW, Borysiewicz LK, Man S. Human papillomavirus-specific cytotoxic $\mathrm{T}$ lymphocytes in patients with cervical intraepithelial neoplasia grade III. Cancer research. 1997; 57: 4855-61.

17. Yang W, Song Y, Lu YL, Sun JZ, Wang HW. Increased expression of programmed death (PD)-1 and its ligand PD-L1 correlates with impaired cell-mediated immunity in high-risk human papillomavirus-related cervical intraepithelial neoplasia. Immunology. 2013; 139: 513-22.

18. Chapoval AI, Ni J, Lau JS, Wilcox RA, Flies DB, Liu D, et al. B7-H3: a costimulatory molecule for $\mathrm{T}$ cell activation and IFN-gamma production. Nature immunology. 2001; 2: 269-74.

19. Sica GL, Choi IH, Zhu G, Tamada K, Wang SD, Tamura H, et al. B7-H4, a molecule of the B7 family, negatively regulates $\mathrm{T}$ cell immunity. Immunity. 2003; 18: 849-61.

20. Chen L, Xie Q, Wang Z, Shi L, Wu C, Jiang J. Assessment of combined expression of $\mathrm{B} 7-\mathrm{H} 3$ and $\mathrm{B} 7-\mathrm{H} 4$ as prognostic marker in esophageal cancer patients. Oncotarget. 2016; 7: 77237-43.

21. Reuschenbach M, Wentzensen N, Dijkstra MG, von Knebel Doeberitz M, Arbyn M. p16INK4a immunohistochemistry in cervical biopsy specimens: A systematic review and meta-analysis of the interobserver agreement. American journal of clinical pathology. 2014; 142: 767-72.

22. Kurshumliu F, Thorns C, Gashi-Luci L. p16INK4A in routine practice as a marker of cervical epithelial neoplasia. Gynecologic oncology. 2009; 115: $127-31$.

23. Yildirim $\mathrm{M}$, Muller von der Grun J, Winkelmann $\mathrm{R}$, Fokas $\mathrm{E}$, Rodel $\mathrm{F}$, Ackermann $\mathrm{H}$, et al. Combined p16 and p53 expression in cervical cancer of unknown primary and other prognostic parameters : A single-center analysis. Strahlentherapie und Onkologie : Organ der Deutschen Rontgengesellschaft [et al]. 2017; 193: 305-14

24. Jia WL, Ding L, Ren ZY, Wu TT, Zhao WM, Fan SL, et al. [Effects of both folic acid, p16 protein expression and their interaction on progression of cervical cancerization]. Strahlentherapie und Onkologie : Organ der Deutschen Rontgengesellschaft [et al]. 2016; 37: 1647-52.

25. Chen L, Chen J, Xu B, Wang Q, Zhou W, Zhang G, et al. B7-H3 expression associates with tumor invasion and patient's poor survival in human esophageal cancer. American journal of translational research. 2015; 7: 2646-60.

26. Wang L, Zhang Q, Chen W, Shan B, Ding Y, Zhang G, et al. B7-H3 is overexpressed in patients suffering osteosarcoma and associated with tumor aggressiveness and metastasis. PloS one. 2013; 8: e70689.

27. Wu CP, Jiang JT, Tan M, Zhu YB, Ji M, Xu KF, et al. Relationship between co-stimulatory molecule B7-H3 expression and gastric carcinoma histology and prognosis. World journal of gastroenterology. 2006; 12: 457-9.

28. Dong C, Nurieva RI, Prasad DV. Immune regulation by novel costimulatory molecules. Immunologic research. 2003; 28: 39-48.

29. Suh WK, Gajewska BU, Okada H, Gronski MA, Bertram EM, Dawicki W, et al. The B7 family member B7-H3 preferentially down-regulates T helper type 1-mediated immune responses. Nature immunology. 2003; 4: 899-906.

30. Prasad DV, Nguyen T, Li Z, Yang Y, Duong J, Wang Y, et al. Murine B7-H3 is a negative regulator of T cells. Journal of immunology. 2004; 173: 2500-6.

31. Fukushima A, Sumi T, Fukuda K, Kumagai N, Nishida T, Yamazaki T, et al. B7-H3 regulates the development of experimental allergic conjunctivitis in mice. Immunology letters. 2007; 113: 52-7.

32. Ling V, Carreno BM, Collins M. Isoforms of human B7-H3 co-signalling molecule for $\mathrm{T}$ cell activation as potential immunoregulatory agents. Expert opinion on therapeutic patents. 2005; 15: 745-9.

33. zur Hausen H. Papillomaviruses causing cancer: evasion from host-cell control in early events in carcinogenesis. Journal of the National Cancer Institute. 2000; 92: 690-8 